\title{
Fresh Start or Head Start? The Effect of Filing for Personal Bankruptcy on the Labor Supply*
}

\author{
Song Han \\ The Federal Reserve Board \\ Wenli $\mathrm{Li}^{\dagger}$ \\ The Federal Reserve Bank of Philadelphia
}

April 28, 2004

\begin{abstract}
The key feature of the modern U.S. personal bankruptcy law is to provide debtors a financial fresh start through debt discharge. The primary justification for the discharge policy is to preserve human capital by maintaining incentives for work. In this paper, we test this fresh start argument by providing the first estimate of the effect of personal bankruptcy filing on the labor supply using data from the Panel Study of Income Dynamics (PSID). Our econometric approach controls for the endogenous self-selection of bankruptcy filing and allows for dependence over time for the same household. We find that filing for bankruptcy does not have a positive impact on annual hours worked by bankrupt households, a result mainly due to the wealth effects of debt discharge. The finding is robust to a number of alternative model specifications and sample selections. Therefore, our analysis does not find supporting evidence for the human capital argument for bankruptcy discharge.
\end{abstract}

JEL Classifications: J22, K35, D14

\footnotetext{
${ }^{*}$ For their valuable comments, we thank Mitchell Berlin, Satyajit Chatterjee, Darrel S. Cohen, Ronel Elul, Jonathan Fisher, Melissa Jacoby, Ethan Lewis, Nellie Liang, Mike Salemi, Tarun Sarbawal, Nick Souleles, Michelle White, and seminar participants at the University of North Carolina at Chapel Hill, the 2004 American Economic Association Meetings, and the Federal Reserve Bank of Philadelphia. The opinions expressed in this paper do not necessarily represent those of the Federal Reserve Board, the Federal Reserve Bank of Philadelphia, or the Federal Reserve System.

${ }^{\dagger}$ Song Han: Division of Research and Statistics, Stop 89, Board of Governors of the Federal Reserve System, Washington, D.C. 20551. Song.Han@frb.gov. Wenli Li, Department of Research, Federal Reserve Bank of Philadelphia, Ten Independence Mall, Philadelphia, PA 19106. Wenli.li@phil.frb.org.
} 
Neither a borrower nor a lender be;

For loan oft loses both itself and friend,

And borrowing dulls the edge of husbandry.

- William Shakespeare, Hamlet, act I, scene 3

\section{Introduction}

The key feature of modern U.S. law on personal bankruptcy is debt forgiveness. A debtor who files for bankruptcy can obtain a discharge from most of his existing debts after surrendering either some of his current assets or a portion of his future earnings. ${ }^{1}$ Since discharge not only releases the debtor from past financial obligations but also protects him from some of the adverse consequences that may otherwise result from that release, ${ }^{2}$ it is viewed as granting the debtor a financial fresh start.

The primary goal of the fresh start policy is to preserve human capital by providing incentives to work. ${ }^{3}$ As the U.S. Supreme Court pointed out in its influential ruling in Local Loan Co. v. Hunt (1934), bankruptcy discharge "gives to the honest but unfortunate debtor...a new opportunity in life and a clear field for future effort, unhampered by the pressure and discouragement of pre-existing debt." Without debt discharge, "from the viewpoint of the wage-earner there is little difference between not earning at all and earning wholly for a creditor." That is, as an insolvent debtor devotes more of his energies and resources to leisure and other activities that frustrate creditors' collection efforts, he not only decreases his productive contributions to society but also generates deadweight loss.

The belief that bankruptcy discharge fosters greater industriousness has long been held in the United States. In 1755, nearly two centuries before the ruling in Local Loan Co. $v$. Hunt and almost a half-century before the enactment of the first federal bankruptcy law in 1800, an anonymous author wrote in the first published argument for outright bankruptcy

\footnotetext{
${ }^{1}$ The debt discharge is at the cost of current assets if the debtor files under Chapter 7 of the bankruptcy law, and of future earnings if he files under Chapter 13. Bankruptcy discharge is a nonwaivable right which can be denied only if a debtor has violated some norm of behavior (e.g., fraud) specified by the law. Certain debts, such as child support, however, are not dischargable. See U.S.C. Title 11-Bankruptcy, Sec. 727.

${ }^{2}$ Credit bureaus may keep and disseminate bankruptcy records for only ten years.

${ }^{3}$ There are other justifications for the debt discharge. For example, discharge allows risk sharing because creditors are thought to be superior risk bearers than debtors. Discharge may also be a better policy than other safety-net programs in dealing with household insolvency because it shifts the task of monitor to creditors, who are more efficient than the general public in screening and monitoring borrowers. Thus, it alleviates the moral hazard problem commonly associated with other social welfare programs that debtors might rely on if there were no debt discharge (Jackson 1998). See also Hirsch (1994), who wrote that "the idea of the fresh start can be probed from half a hundred different pedagogical angles" (page 202).
} 
discharge that if the debtor can "begin the world anew, he might be encouraged to frugality and industry." "Surprisingly, despite the prominence of this belief, no formal economic study has examined this issue. In this paper, we seek to bridge the gap in the literature and to provide the first estimate of the effect of filing for personal bankruptcy on the labor supply. This study is important because it sheds light on the efficiency consequences of the current bankruptcy system and indicates the extent of bias in those welfare studies of bankruptcy that do not account for bankruptcy-induced changes in the labor supply.

Using a simple static model, we first highlight forces that work either for or against the fresh start logic. First, positive wealth effects are associated with personal bankruptcy filing. Under the current bankruptcy provisions, all unsecured debt owed by the bankrupt is discharged, but only some assets are seized. As long as the value of the seized assets does not exceed that of the discharged debt, debtors will be richer upon filing for bankruptcy. This positive wealth effect implies that debtors will work less hard in bankruptcy than they would if they had to repay all debt. Second, a debtor can simply default on his debt without filing for bankruptcy, in which case creditors' collection practice is governed by state insolvency laws. Since insolvency laws do not have provisions for debt discharge, creditors can grab any of the debtor's assets-both current and future-outside some limited exemptions until, in principle, all debt is paid. Some states also allow creditors to collect through wage garnishment. These collection efforts can establish an effective tax levy on earnings, which provides negative incentives for work and positive incentives for "tax evasion." Filing for bankruptcy may reduce these disincentives for work, and, as a result, induce higher labor supply to the marketplace. As the net effects of the above two forces are ambiguous, they must be measured empirically.

Using the data from the Panel Study of Income Dynamics (PSID), we estimate the effect of bankruptcy filing on households' annual hours worked. In our analysis, we control for the endogenous selectivity of bankruptcy filing. We also allow for dependence over time for the same household to control for unobserved and household-specific heterogeneity. We find that bankruptcy filing does not have a positive impact on households' annual hours worked. To the contrary, consistent with our theory, all the corresponding coefficients from our estimation equations have negative signs, although these coefficients are not statistically significant at the usual levels. These findings are robust to a number of alternative sample selections and model specifications.

Our results suggest that current personal bankruptcy provisions do not provide any

\footnotetext{
4 "Some Reflections on the Law of Bankruptcy Wrote at the Desire of a Friend, Shewing, That Such a Law Would Be Beneficial to the Publick, and Analogous to Reason and Our Holy Religion, and by Him Humbly Recommended to the Consideration of the Publick." (New-Haven: Printed by James Parker. 1755).
} 
positive work incentives. Therefore, we should not take for granted the validity of the fresh start argument when evaluating the welfare consequences of the personal bankruptcy law or when proposing new changes. ${ }^{5}$ That said, our analysis does not rule out the role of the personal bankruptcy law as a social insurance program. Indeed, using data on food consumption provided by the PSID, we find that bankrupt households consumed more under bankruptcy filing than they would have if they did not file. The estimate, however, is statistically insignificant.

This paper addresses three strands of literature. First, it contributes to the many studies that examine the factors leading to personal bankruptcy, and it responds to the growing interests in the impact of personal bankruptcy on consumer behavior. Among these studies, Domowitz and Sartain (1999) show that medical and credit-card debt is an important factor in households' decision to file for bankruptcy and in their selection of the chapter under which they file. Fay, Hurst and White (2002) find that financial benefits and social stigma also play important roles in households' bankruptcy filing decision. Buckley and Brinig (1998), and Gross and Souleles (2002) find that in recent years, declining social stigma is consistent with an increasing propensity to file for bankruptcy. Gropp, Scholz and White (1997) and Lin and White (2001) study how bankruptcy laws affect the supply of and demand for credit. They show that generous state-level bankruptcy exemptions increase the amount of credit held by high-asset households and reduce the availability and amount of credit extended to low-asset households. Although Elul and Subramanian (2002) find that differences in bankruptcy laws motivate households to "forum shop," or move to a state with a higher exemption before declaring bankruptcy, these authors note that the actual effect is relatively modest. Repetto (1998) shows that the protection of assets by bankruptcy discourages saving. Finally, Sullivan, Warren and Westbrook(2000) provide a detailed description of the financial circumstances of those who file for bankruptcy. Although our focus-the effects of personal bankruptcy on the labor supply-has been at the center of legislations on bankruptcy issues, it has been largely ignored in this literature.

Second, this paper also contributes to the larger literature on the effects of social insurance programs and laws on the labor supply. Previous works have extensively examined the various wealth and substitution effects caused by social institutions, a tradition that our paper follows here. For example, Moffitt (2002) reviews the literature on how one popular social insurance program, Aid to Families with Dependent Children (AFDC), has affected the labor supply. Existing studies found almost universally that the program reduced the labor supply by 10 percent to 50 percent of non-AFDC levels. See also Krueger and Meyer

\footnotetext{
${ }^{5}$ See, for example, Mester (2002) for a discussion on the components of recent bankruptcy reform proposals.
} 
(2002) for a comprehensive review of the recent literature on other programs,

Finally, this paper fills in a gap left by the growing number of studies that use equilibrium approaches to characterize the quantitative features of an economy in which agents have the option to default. These studies evaluate the effects of changes in bankruptcy laws on the welfare of the economy. Recent works of this kind include Athreya (2002); Chatterjee, Corbae, Nakajima and Rios-Rull (2002); Li and Sarte (2003); and Livshits, MacGee and Tertilt (2001). All of these papers emphasize the risk-sharing aspect of the bankruptcy law, and either leave out the labor market completely or model it in a minimal way.

The rest of the paper is organized as follows. Section 2 presents our model of bankruptcy and labor supply. Section 3 then discusses the empirical methodology, the data, and the empirical results. Section 4 reports the results from additional tests of robustness. Finally, Section 5 concludes.

\section{Theoretical Background}

In this section, we outline a simple static model to characterize personal bankruptcy and labor supply decisions. Our main purpose here is to highlight the different forces that work for or against the "fresh start" argument and to guide our empirical analysis.

Agents in our model live for one period. They value both consumption and leisure, and they make decisions to maximize their period utility $U(c, 1-l)$, where $c(c>0)$ denotes consumption, and $l(0 \leq l \leq 1)$ denotes labor supply with time endowment normalized to 1 . The utility function exhibits the usual properties of monotonicity and concavity and satisfies the Inada conditions with respect to both inputs. We further assume that consumption and leisure are substitutable.

Consider an individual who has the right of filing for bankruptcy. He begins the period with assets $a$ and debt $d$, where $d$ includes the principal plus the interest. After he receives his wage rate $w$, he decides how much labor, $l$, to supply and whether to file for bankruptcy. If he files for bankruptcy, ${ }^{6}$ as noted earlier, he must surrender all of his assets exceeding a predetermined exemption level. In exchange, all of his eligible debt is discharged. Let $e$ represent the level of asset exemption. Then

$$
c=\min (\alpha a, e)+w l .
$$

\footnotetext{
${ }^{6}$ Data limitation precludes us from separating the effects of Chapter 7 versus Chapter 13 in the empirical analysis. We, therefore, focus solely on bankruptcy filing under Chapter 7. In practice, over 70 percent of personal bankruptcy filings in the United States are under Chapter 7, and one-third of the Chapter 13 filings are later converted into Chapter 7.
} 
We assume $0 \leq \alpha \leq 1$ to allow the auction value of the assets turned over to the bankruptcy trustee to be less than what they are worth to their owner, and to capture bankruptcy filing fees. ${ }^{7}$ This difference may be due to the cost of fire sale or to the extra sentimental value that their owner attaches to the assets.

If he does not file for bankruptcy, then

$$
c=a+w l-q(w l, d)
$$

where $q(w l, d)=d$ when the borrower repays his debt, and $q(w l, d)=\tau w l$ when the borrower does not repay his debt and wage garnishment takes place. The wage garnishment rate, $\tau$, is assumed to be weakly increasing in debt $(d)$ and decreasing in wages $(w l)$. For simplification, we further assume that the borrower cannot conceal his assets or income from his creditors. ${ }^{8}$ As a result, when the debtor has the resources to repay the debt and does not file for bankruptcy, he will choose to repay the debt, because he cannot gain anything by simply defaulting and having his wage garnished.

Finally, we assume that a debtor incurs certain costs, as modeled by a utility loss $s>0$, when filing for bankruptcy. These costs can be pecuniary and nonpecuniary. First, under the law, individuals who file under Chapter 7 become ineligible for Chapter 7 bankruptcy within six years. Since the option to file for bankruptcy is valuable, forgoing it for the next six years is costly. Second, a bankruptcy filing remains on public record for ten years. With such a record on credit history, individuals are more likely to be excluded from credit markets or have to borrow at higher rates (Musto 2002). Third, bankruptcy imparts a social stigma (Buckley and Brinig 1998, Fay, Hurst, and White 2002, and Gross and Souleles 2002). To illustrate our main points, we first assume that these losses occur independently of the individual's behavior except for the action of filing for bankruptcy. This is obviously a strong assumption. Later we discuss how the relaxation of this assumption, among other things, affects our results. We will also argue that our empirical analysis requires that only some of these losses-specifically, social stigma-are independent of the labor supply decision. ${ }^{9}$

\footnotetext{
${ }^{7}$ Debtors must also pay fees for filing bankruptcy and for legal services. Bankruptcy filing fees are often as low as $\$ 100$ in large cities. The legal fees typically range from $\$ 750$ to $\$ 1,500$ (Sullivan, Warren, and Westbrook 2000).

${ }^{8}$ One can assume that $\tau$ may also depend on the amount of time that the debtor spends in evading the "tax." While interesting, it adds unnecessary complications to our analysis.

${ }^{9}$ There may also be utility cost associated with having one's wage garnished. Since we do not separately model the decision of repaying the debt and having wage garnished, we normalize the cost to zero.
} 


\subsection{An Individual's Problem}

An individual chooses his consumption $c$, labor $l$, and payment decisions $I$ to solve the following maximization problem:

$$
\max _{c \geq 0,0 \leq l \leq 1, I \in\{0,1\}} U(c, 1-l)-s I
$$

where $I=0$ if the borrower does not file for bankruptcy, and $I=1$ otherwise.

Let $V^{R}$ and $V^{B}$ denote the individual's maximum utility under the option of not filing for bankruptcy and filing for bankruptcy, respectively. Then,

$$
\begin{aligned}
V^{R} & =\max _{l} U(a+w l-q(w l, d), 1-l), \\
V^{B} & =\max _{l} U(\min (\alpha a, e)+w l, 1-l)-s .
\end{aligned}
$$

We can think of an individual making decisions in two steps. He first computes the optimal levels of consumption and labor, and hence the utilities associated with not filing for bankruptcy and with filing for bankruptcy. Then he selects the option that gives him the highest utility. We now characterize the two-step decision rules.

\subsection{The Labor Supply Decision}

An individual chooses his optimal labor supply by solving the following first order conditions: ${ }^{10}$

$$
w\left[1-q_{1}(w l, d)\right] U_{1}(a+w l-q(w l, d), 1-l)-U_{2}(a+w l-q(w l, d), 1-l)=0
$$

if he does not file for bankruptcy; and

$$
w U_{1}(\min (\alpha a, e)+w l, 1-l)-U_{2}(\min (\alpha a, e)+w l, 1-l)=0
$$

if he files for bankruptcy. Denote the labor supply decisions under the two options by $l^{R}$, and $l^{B}$, respectively.

There are two possibilities in the non-bankruptcy state. In the first case, the debtor repays his debt, i.e., $q(w l, d)=d$. Then, when the debtor loses more assets under debt repayment than under bankruptcy, that is, $a-d \leq \min (\alpha a, e)$, bankruptcy filing induces a positive wealth shock. This wealth shock, in turn, lowers the debtor's labor supply and increases his consumption of leisure in bankruptcy.

\footnotetext{
${ }^{10}$ The Inada conditions ensure that households will choose both consumption and leisure in positive amounts.
} 
In the second case, wage garnishment occurs, i.e., $q(w l, d)=\tau(w l, d) w l$. Then, when $a-\tau w l \leq \min (\alpha a, e)$, the borrower would still incur a positive wealth shock by filing for bankruptcy, and the associated wealth effect will create a disincentive to work. However, the wage garnishment now serves effectively as a wage tax. Thus, by substitution effect, it would reduce the incentive to work in the non-bankruptcy state. Whether the debtor would work less under bankruptcy filing than under wage garnishment depends on whether the wealth effect dominates the substitution effect.

Finally, although we do not explicitly consider Chapter 13 filing, we can analyze it within our framework. In essence, a Chapter 13 repayment plan works very much like the wage garnishment but with partial debt discharge. As a result, the wealth effect and the substitution effect would both discourage a debtor from exerting work effort under Chapter 13.

\subsection{Bankruptcy Decision}

A debtor's decision to file for bankruptcy is entirely determined by the utility the option delivers. Specifically,

$$
I= \begin{cases}0 & \text { if } V^{R} \geq V^{B} \\ 1 & \text { otherwise. }\end{cases}
$$

Because of the utility loss associated with filing for bankruptcy, it is obvious that a debtor would consider bankruptcy filing only if $a-d \leq \min (\alpha a, e)$. It is easy to show that debtors with more debt are more likely to file for bankruptcy. This is because the value of filing for bankruptcy $\left(V^{B}\right)$ does not vary with the level of debt $(d)$, while the value of not filing for bankruptcy decreases with debt under our assumption that the percent of wage garnished $(\tau)$ increases with debt $(d)$.

In terms of assets, it is clear that the utility associated with no bankruptcy filing $\left(V^{R}\right)$ increases with asset holdings $(a)$ while the utility associated with bankruptcy filing $\left(V^{B}\right)$ initially increases with $a$ until $\alpha a=e$, and then it becomes invariant to the changes in the assets. This suggests the existence of an asset threshold above which debtors will never choose to file for bankruptcy.

\subsection{Summary}

To sum up, a borrower's propensity to file for bankruptcy increases with his debt and decreases with his assets. Filing for bankruptcy induces positive wealth effect, and this effect will reduce the incentive to work. This implies that, without wage garnishment, a debtor will work less hard under bankruptcy than when he does not file for bankruptcy. With wage garnishment, however, whether the debtor works less under bankruptcy depends on whether 
the wealth effect induced by debt discharge dominates the substitution effect induced by wage garnishment.

Our results regarding both labor supply and bankruptcy decisions will obviously be dampened if we relax several of the model's key assumptions. For instance, in a dynamic setting, because bankrupt households will have difficulty obtaining access to the credit market, they may want to work harder and save more to insure against future adverse events. The above simple framework nevertheless demonstrates that, contrary to the long-held fresh start view, certain forces can induce less work effort under debt discharge.

\section{Empirical Analysis}

\subsection{Empirical Strategy}

At each period, households make two decisions simultaneously: whether to file for bankruptcy and how much labor to supply. The bankruptcy decision is determined by the following equation:

$$
\Delta=Y \gamma+\varepsilon
$$

such that $I=1$ if $\Delta>0$ and $I=0$ otherwise. We denote a household's desired labor supply in the states of bankruptcy and nonbankruptcy by $l^{B}$ and $l^{R}$, respectively. We assume that

$$
\begin{aligned}
& \log l^{R}=X \alpha+v^{R} \\
& \log l^{B}=Z \beta+v^{B} .
\end{aligned}
$$

Denote the observed labor supply in the data by $l$. Then

$$
\begin{aligned}
\log l & =(1-I) \log l^{R}+I \log l^{B} \\
& =X \alpha+I(Z \beta-X \alpha)+\eta
\end{aligned}
$$

where $\eta=v^{R}+I\left(v^{B}-v^{R}\right)$. The vectors $X, Y$ and $Z$ contain factors that affect households' labor supply and bankruptcy decisions, and $v^{R}, v^{B}$ and $\varepsilon$ are error terms that may be correlated with each other but are orthogonal to $X, Y$ and $Z$. In this paper we estimate a restricted version of the above model by assuming that the conditional means of $\log l^{B}$ and $\log l^{R}$ differ only in the constant, that is, $X=Z$ and $\beta=\alpha$ except that $\beta_{0} \neq \alpha_{0}$. We impose this restriction mainly due to data limitations discussed later. This practice is also common in the program evaluation literature. Accordingly, equation (11) becomes

$$
\log l=X \alpha+I \hat{\beta}+\eta
$$


with $\hat{\beta}=\beta_{0}-\alpha_{0}$.

As in the literature on program evaluation, the parameter that most interests the policy maker is the "treatment effect on the treated." 11 In our case, the question becomes whether and to what extent a bankrupted individual works harder than he would if he had not filed for bankruptcy. In other words, the statistic we are interested in is

$$
E\left(\log l^{B}-\log l^{R} \mid X, Y, I=1\right)=\hat{\beta}+E\left(v^{B}-v^{R} \mid X, Y, I=1\right) .
$$

Bankruptcy decisions are endogenous and may be correlated with the error terms of the labor supply equations. In this case, the explanatory variable $I$ in equation (12) is not orthogonal to $\eta$. As a result, a simple least squared regression of (12) will produce a biased estimate of $\hat{\beta}$, which in turn leads to a biased estimate of (13).

In the program evaluation literature, two main approaches have often been used to solve the above issue. The first approach is to explicitly characterize the selection bias just noted. More precisely, assume that $\varepsilon, v^{R}, v^{B}$ are jointly normally distributed according to

$$
\left[\varepsilon, v^{R}, v^{B}\right] \sim N\left(\begin{array}{lll}
1 & \rho^{R} \sigma^{R} & \rho^{B} \sigma^{B} \\
\rho^{R} \sigma^{R} & \left(\sigma^{R}\right)^{2} & \rho^{R B} \sigma^{R} \sigma^{B} \\
\rho^{B} \sigma^{B} & \rho^{R B} \sigma^{R} \sigma^{B} & \left(\sigma^{B}\right)^{2}
\end{array}\right) .
$$

Taking expectation of our labor supply function (12) conditional on $X, Y$ and $I$, after some rearrangements we have

$$
E(\log l \mid X, Y, I)=X \alpha+\hat{\beta} I+\rho^{R} \sigma^{R}(1-I) \frac{-\phi(Y \gamma)}{1-\Phi(Y \gamma)}+\rho^{B} \sigma^{B} I \frac{\phi(Y \gamma)}{\Phi(Y \gamma)},
$$

where $\phi$ and $\Phi$ are, respectively, the density and the cumulative distribution functions of a normal distribution with mean 0 and variance 1 . We call $(1-I) \frac{-\phi(Y \gamma)}{1-\Phi(Y \gamma)}$ the inverse Mill's ratio for the repaid, and $I \frac{\phi(Y \gamma)}{\Phi(Y \gamma)}$ the inverse Mill's ratio for the bankrupt. Under the above assumptions, the treatment effect on the treated, (13), is equal to

$$
E\left(\log l^{B}-\log l^{R} \mid X, Y, I=1\right)=\hat{\beta}+\left(\rho^{B} \sigma^{B}-\rho^{R} \sigma^{R}\right) \frac{\phi(Y \gamma)}{\Phi(Y \gamma)},
$$

evaluated at the mean of all explanatory variables of the sample consisting of only bankrupted households. We label this approach the Contemporaneous Selection Control strategy. For example, Ruhm (1997) and Jappelli, Pischke and Souleles (1998) have used this approach in their research. We will use this strategy in our main analysis.

\footnotetext{
${ }^{11}$ Another parameter often estimated is the effect of treatment on a randomly chosen person. It is the coefficient $\hat{\beta}$ in (12). See Heckman, Lalonde, and Smith (1999) for detailed discussions on what parameters matter most for the policy maker.
} 
We implement the above strategy in two steps. First, we use a Probit regression to estimate the household's bankruptcy decision, from which we compute the two inverse Mill's ratios in (14). Then, we substitute the estimated inverse Mill's ratios for their population counterparts in (14), and use simple OLS regressions to estimate it. We obtain the standard errors of all estimates through bootstrap methods; in drawing bootstrap samples, we allow for dependence across observations over time for the same households.

Equation (14) implies that we can identify the model based on the nonlinearity of the estimated inverse Mill's ratios. However, a robust identification entails an instrumental variable (IV) for the endogenous bankruptcy variable $I$. The IV should satisfy the requirements that it affects the household's bankruptcy decision but does not affect directly the desired labor supply, except through its effect on the filing propensity. A measure of social stigma or attitude toward personal bankruptcy would meet such requirements. The problem is that these personal preferences are not directly observable. However, previous authors, such as Fay, Hurst and White (2002) and Elul and Subramanian (2002), suggested that they may depend on the number of people in the local areas who filed for bankruptcy in recent years. The idea is that an individual may feel less stigma in filing for bankruptcy if a lot of people have also done that, a phenomena often called "peer effect." The lagged state bankruptcy filing rate, therefore, serves our purpose. We also include in our control variables lagged state unemployment rate and lagged state income growth rate to control for the state economic environment that presumably may also influence the lagged state bankruptcy filing rate.

A second approach to solve the endogenous selection issue is an Instrumental Variable (IV) approach, and it is well documented in Heckman, Lalonde, and Smith (1999). Under this approach, certain assumptions are made on the model structure such that the second term of (13) equals zero. Two alternative assumptions are often invoked: $E\left(v^{B}-v^{R} \mid X, Y, I=1\right)=0$, or $v^{B}=v^{R}$ (see Heckman, Lalonde, and Smith 1999 for details). As a result, the treatment effect on the treated is measured by $\hat{\beta}$ alone. To eliminate the covariance between $I$ and $v^{R}$, we apply an IV method to equation (12), which allows us to obtain an unbiased estimate of $\hat{\beta}$. The IV should meet the same requirements as in the Contemporaneous Selection Control strategy. Therefore, we also use the lagged state bankruptcy filing rate as our IV. Later we also present estimates based on this approach.

Again, we implement this Instrumental Variable approach in two steps. First, the same Probit regression is run to estimate the household's bankruptcy decision, from which we compute the predicted probability of filing for bankruptcy. Then, we replace $I$ in equation (12) with the predicted probability, and use simple OLS regressions to estimate it. We obtain the standard errors of all estimates through bootstrap methods; in drawing bootstrap samples, we allow for dependence across observations over time for the same households. 


\subsection{Data}

The data we use in this study are taken from the University of Michigan Panel Study of Income Dynamics (PSID). ${ }^{12}$ In 1996, the PSID asked respondents whether they had ever filed for bankruptcy and, if so, in what year(s). Our data set is a combined cross-section, time-series sample of PSID households in the years 1984-1996. For households to be included in the sample, they must have answered the PSID questionnaires in 1996. Moreover, if a household filed for bankruptcy in year $t$, we drop the observations on that household in later years. ${ }^{13}$ Our raw PSID sample comprises of 66, 810 observations with 7,941 families. Observations were deleted for the following reasons:

- The head of household was under age eighteen or over age sixty-five (7,942 observations).

- The head of household was retired, a student, in jail, or permanently disabled (3, 370 observations).

- Hours worked by the head of household exceeded 5, 096 hours a year or 14 hours a day (84 observations).

- Total hours that the head of household spent working, unemployed, on strike, out of labor force, and nursing an illness (self or family members) exceeded 7,080 hours a year or 20 hours a day (3 observations).

- Information on the head of household's age, education, marital status, number of children, self-employment status, state of residence, hours worked, family income, employment status, and health status was missing (6, 577 observations).

The final sample consisted of 48,834 observations on 6,837 households. The maximum number of years over which we observe a household was 13; fifty percent of the households were observed for 6 years or more.

Our sample contains 213 bankruptcy filings, and the proportion of households that filed for bankruptcy by year averaged 0.45 percent in the sample period, which is lower than

\footnotetext{
${ }^{12}$ The PSID is a longitudinal survey that has followed a nationally representative, random sample of families and their extensions since 1968. The survey provides detailed economic and demographic information for a sample of households. At five-year intervals from 1984 through 1999, a wealth supplement to the PSID surveyed the assets and liabilities of each household.

${ }^{13}$ We do so because, as noted earlier, households that file under Chapter 7 are barred from filing again under Chapter 7 for six years. Chapter 13 filers are often not allowed to file again within 180 days of the previous filing. Our regression results are virtually unchanged if we include the bankrupt households.
} 
the national average of 0.7 percent over the same period. Our relatively low percentage may result from the underreporting of bankruptcy filings by the households in our sample. However, this underreporting did not significantly bias our estimates. As noted in Fay, Hurst, and White (2002), as long as the number of households that actually went bankrupt but lied about it in the survey is small relative to the number of households that actually did not file for bankruptcy, a condition that seems to hold in our sample, the underreporting of bankruptcy filings will lead to a minuscule bias in the estimates (see also Hausman, Abrevaya, and Scott-Morton 1998).

We now discuss the constructions of the key variables used in our empirical analysis. First, our theory suggests that unsecured debt and nonexempt assets at the time of the filing are two important financial variables affecting a household's bankruptcy decision. Information that is required to compute the two variables is from the following sources. The PSID collected information on house equity every year; it also collected detailed wealth data in 1984, 1989 and 1994, including the amount of unsecured debt and the value of non-housing wealth. As proxies for the unsecured debt and other non-housing wealth in the years not covered by the wealth surveys, we use the data from the most recent wealth survey.

Our measure of unsecured debt takes into account the state laws on deficiency judgment. Deficiency judgment is a judgment against a borrower in favor of the lender in an amount equal to the difference between the funds received from a court sale of property and the balance remaining on a mortgage or other secured loan. Such judgments are not allowed in some states. Thus, our unsecured debt variables equals the PSID reported unsecured debt plus, for states that allow for deficiency judgment, any negative home equity. We obtain information on the state laws on deficiency judgment from Keyles (1995) and Jankowski (1999).

To compute nonexempt assets, we also need to know bankruptcy exemptions. Table 1 reports our measures of exemptions by state for 1983 and 1992. Some states experienced changes in either homestead or nonhomestead exemptions or both after 1992, and we report these changes in Table 2. As we can see, both homestead and nonhomestead exemptions vary widely across states, from under $\$ 100$ to unlimited. In calculating these exemptions, we use the 1983 values from Gropp, Scholz and White (1997) for the years 1984-1991, use the 1992 values from White (1998) for 1992-1996 for the states that did not experience any changes, and values from Lin and White (2001) for the states that have experienced changes between 1993 and 1996. When state laws permit households to choose a federal exemption, we use the federal exemption if it is higher than the state exemption. We also account for the states that allow double exemptions for married households. In contrast, however, with the practice of other researchers, such as Fay, Hurst, and White (2002) and Elul and Subramanian 
(2002), we do not lump together homestead and nonhomestead exemptions. Our measure of nonexempt assets, therefore, equals nonhomestead assets minus nonhomestead exemptions plus the part of the home equity that exceeds homestead exemption.

Another key variable is the sate garnishment laws, as it indicates the maximum rate of the "wage tax" when an insolvent debtor simply defaults and allows his creditors to garnish his wage. Most states either set no maximum wage garnishment level-in which case the federal 25\% maximum applies-or set a percentage below the federal level. In particular, six states outlaw wage garnishment altogether. Table 3 summarizes this information.

We use households' reported annual work hours as our benchmark measure for labor supply. Given that in our final sample, there is no household with zero labor hours worked for any given year, we use logarithm of the hours in the estimation. We calculate the hourly wage rate by dividing the reported earnings of the heads of households by their reported work hours. We obtain the macroeconomic and other law variables from the following sources: the state bankruptcy filing rate, from the Administrative Office of the U.S. Courts; the growth rate of state household income and the state unemployment rate, from the Bureau of Economic Analysis.

To choose other variables, we follow the suggestion of our theoretical model as well as the traditions of the literature on bankruptcy decision and labor supply. Table 4 presents descriptive statistics of key variables for the entire sample and for the bankruptcy subsample. As shown, compared with the average household in the overall sample, the heads of bankrupt households are younger, more likely be female, less likely to own houses or businesses, less likely married, but tend to have more kids; they are also more likely to have experienced adverse events such as bad health, periods of unemployment, or divorce. In addition, they worked similar hours but earned lower wage rates. Among the married households, the wives of the bankrupt households tend to be younger, less educated and earned lower wage rates than those of the overall sample. The other striking finding is that bankruptcy filers have higher unsecured debt and lower nonexempt assets. Consequently, financial benefits of personal bankruptcy filing-defined as the difference of the wealth in filing for bankruptcy and in repaying debt-are significantly higher for the bankrupt households than for the average household in the overall sample. This finding indicates that financial gains may be an important factor in households' decision to file for bankruptcy. Finally, bankrupt households worked fewer combined hours by both the head and the wife and have lower family income than does the average household in the overall sample. ${ }^{14}$

\footnotetext{
${ }^{14}$ Family income in the PSID comprises the labor, asset, and transfer income of the husband, the wife, and other family members.
} 


\subsection{Estimation Results}

\subsubsection{Bankruptcy Choice}

We use a Probit regression to estimate households' choice between bankruptcy and no bankruptcy. Our theory dictated how we select the explanatory variables. We include information on households' wealth situation as characterized by nonexempt assets, unsecured debt,and the interaction of the two terms; income information such as family income excluding head's wage, minimum percentage of wage the head is allowed to keep under state garnishment laws; ${ }^{15}$ individual characteristics, such as age, education, race, martial status, number of children, homeownership, business ownership; and information on adverse events that households experienced in the previous year including divorce, unemployment, and bad health. To control for the aggregate economic environment, we include lagged rates of state unemployment, state income growth, and state bankruptcy filing. We also include time and regional dummies. Finally, to capture the nonlinear effects of some of the variables on bankruptcy filing, we introduce the squared terms of unsecured debt, nonexempt assets, age, and family income.

Table 5 shows the estimation results. We adjust the standard errors to allow for dependence over time within (but not across) households when drawing bootstrap samples. Overall, the results are consistent with our theory and with the empirical results obtained by Fay, Hurst and White (2002) and Elul and Subramanian (2002), both of whom also use the PSID data. The sign of the lagged state bankruptcy filing rate is positive, as predicted, and the coefficient is statistically significant at $95 \%$ confidence level. This result supports our theory about the peer group, or stigma, effect. Financial variables are also important factors in households' bankruptcy decision. Controlling for other things, we find that for the average household, a $\$ 1,000$ increase in unsecured debt raises the probability of filing for bankruptcy by 0.014 percentage point, or, by 3 percent, given that the bankruptcy filing rate for the average household as predicted in our model is 0.45 percentage point. A $\$ 1,000$ increase in households' nonexempt assets reduces the bankruptcy probability by 0.001 percentage point, or by 0.2 percent. This result indicates that at the margin, unsecured debt plays a more significant role than do nonexempt assets in households' bankruptcy decisions.

Among demographic variables, being married and having a large family increase the probability of bankruptcy filing. Previous experience of adverse events including divorce and unemployment increases the probability of bankruptcy filing. Living in a state with harsh garnishment laws as measured by the maximum wage garnishment rate permitted by each state also increases the bankruptcy probability, although not statistically significantly. In

\footnotetext{
${ }^{15}$ The data does not provide any information on whether a debtor's salary is indeed garnished or not.
} 
contrast, having a good income prospect as measured by the head's wage of the previous year decreases the bankruptcy probability. None of the macro variables has a notable effect on the bankruptcy filing of individual households after controlling for family characteristics, time and region. All other variables, such as age of head, homeownership, family income excluding head wage income and unemployment have the expected signs though their coefficients are not statistically significant.

\subsubsection{The Effect of Bankruptcy Filing on Annual Hours Worked by the Head of a Household}

We now turn to the effects of bankruptcy filing on the labor supply. We first present the results estimated using the Contemporaneous Selection Strategy discussed above. We measure the labor supply by the reported hours worked by the head of household in the same year of the bankruptcy decision. As shown in (14), the explanatory variables include a bankruptcy dummy $I$ with $I=1$ if the household filed bankruptcy and $I=0$ otherwise. Lagged hourly wage rate, as calculated by the ratio of reported labor market earnings to hours worked, is included as one of the explanatory variables for the labor supply. Other explanatory variables include the two inverse Mill's ratios constructed from the above bankruptcy regression, and demographic variables such as head's age, age-squared, and education attainment, etc. Note that the lagged state bankruptcy filing rate is the IV for bankruptcy filing, and hence it is not included in the labor supply regression. ${ }^{16}$

We report the regression coefficients and their bootstrap standard errors in Table 6 . Note that the bootstrap samples are drawn by allowing dependence across years for the same households. The effect of bankruptcy filing on the labor supply is computed according to (15) and is shown at the bottom of the table.

As shown, the estimated effect of bankruptcy filing on the labor supply is -0.01 , suggesting that the head of the average bankrupt household reduces the annual labor supply by about 1 percent, or working 20 fewer hours in bankruptcy, comparing to the hours they would work if they did not file. ${ }^{17}$ The estimated coefficient, however, is not statistically significant at the usual confidence levels (90 or 95 percent). Therefore, our benchmark analysis shows that, if anything, bankruptcy filing seems to depress the labor supply of the heads of the bankrupt households.

\footnotetext{
${ }^{16}$ Financial variables are not included either. However, our results are qualitatively robust to including total assets and its square as additional explanatory variables in our labor supply regressions.

${ }^{17}$ To put our estimate to perspect, existing studies found almost universally that the Aid to Families with Dependent Children (AFDC) program reduced the labor supply by 10 percent to 50 percent of non-AFDC levels. See Moffitt (2002) for a literature review of the studies on the AFDC programs.
} 
Our results for other explanatory variables are consistent with those obtained in the literature on the individual labor supply. Heads of household who are older, more educated, and male work longer hours. Homeowners also work longer hours, while business owners work fewer hours. Heads of household with higher family income in the previous year also work more hours. This result suggests that past family income may be a good indicator of future earning potential. Having controlled for family income, head's wage rate of the previous year, however, affects its labor supply negatively. Those heads who experienced health problems or were unemployed in the previous year work significantly fewer hours. Finally, heads of household who live in states with a high unemployment rate in the previous year also supplied fewer labor hours reflecting the impact of reduced demand.

\section{Robustness}

Having presented our benchmark results, we now assess their robustness along the following dimensions. First, we present the estimation results using the alternative Instrumental Variable approach discussed earlier. Second, we re-estimate the model with an alternative definition of labor supply: the total hours worked by both husband and wife. Third, we discuss the choice of instrumental variable and the measurement issues associated with our financial variables. Finally, we use limited consumption information provided in the PSID to explore the welfare implications of personal bankruptcy filing.

\subsection{Evidence from the Instrumental Variable Approach}

As discussed in Section 3.1, the IV approach has been widely used in the literature on program evaluation. Although the IV approach requires stronger assumptions about the error terms than does our benchmark, or the Contemporaneous Selection approach, the results are easier to interpret. In the second regression, the coefficient on the propensity to file, or $\hat{\beta}$, gives us the effect of bankruptcy filing on the labor supply, which is independent of the household's characteristics and the bankruptcy filing status. ${ }^{18}$

The first-stage regression in the IV approach is the same as in the benchmark; therefore, we report only the second-stage regression results (Table 7). As shown, the estimated effect of bankruptcy filing on the labor supply, calculated according to (15), is -0.17 , suggesting that upon filing for bankruptcy, heads of bankrupt households would reduce their work hours by about 15 percent or 330 hours a year, comparing to the hours they would work if they

\footnotetext{
${ }^{18}$ That is, the treatment effect on the treated is the same as the treatment effect on the randomly assigned subject. See Heckman, Lalonde, and Smith (1999).
} 
did not file. Again, as in the benchmark case, the coefficient is not statistically significant at the usual 90 or 95 percent confidence levels. The effects of other control variables remain largely unchanged.

\subsection{Evidence on Annual Hours Worked by the Family}

In this subsection, we use a broader definition of labor supply-total hours worked by husband and wife, or "family hours"-in our analysis. For single or divorced households, their family hours would be the same as the head hours. Among married households, 75 percent of the wives work; among married households who filed for bankruptcy, roughly 80 percent of the wives work.

To control for the characteristics of a spouse, we include in the explanatory variables the wife's age interacted with martial status, the wife's education level interacted with marital status, and the wife's wage (if she works) interacted with marital status. The estimation results of the Contemporaneous Selection approach are shown in Table 8. Now the estimated effect of bankruptcy filing on the family labor supply for bankrupt households, calculated according to (15), is -0.35 . This suggests that upon bankruptcy filing, the average bankrupt household would reduce its family labor supply by about 30 percent, or close to 860 hours a year, comparing to the hours they would work if they did not file. Again, the coefficient is not statistically significant at the usual confidence levels. This is not surprising given that married households most likely make decisions as a unit. Anecdotally, the majority of bankruptcy filings for married couples are joint filings, though this information is not available in the PSID. The effects of other variables on households' labor supply remain roughly unchanged from the results obtained earlier when we considered only the labor hours of household heads.

\subsection{Additional Experiments}

Now we briefly discuss two other issues on the robustness of our results: the selection of the instrumental variable and the potential measurement error associated with the financial variables.

Some may argue that the absolute number of households filing for bankruptcy is a better proxy for the peer effect than the rate of bankruptcy filing. After all, it is often times the number of bankruptcy cases not the rate that catch the media and average households' attention. To test this theory, we experiment using this alternative proxy as our instrumental variable for bankruptcy decision. Indeed, as a factor in the bankruptcy filing decision, the absolute number of bankruptcy filings turns out to be statistically and economically 
significant. But the effect of bankruptcy filing on the labor supply remains negative and statistically insignificant in the new specification.

In calculating our financial variables, we used the annually measured data on home equity, but took the nonhome wealth and unsecured debt from the most recent wealth survey. This approach obviously introduces measurement errors. To assess the importance of this potential mismeasurement, we re-estimate our model using only observations from 1984-1985, 1989-1990, and 1994-1995. Because the PSID has detailed wealth information for 1984, 1989 and 1994, we expect the financial variables to be most accurately measured in those years and in the years immediately after them. ${ }^{19}$ The new sample contains 22,740 observations on 6,110 households with 109 bankruptcy filings. Again, the effect of bankruptcy filing on the labor supply of household heads remains negative and statistically insignificant.

\subsection{Welfare Implications: Consumption Insurance}

Our results so far suggest that households do not increase their labor supply under personal bankruptcy. Nonetheless, bankruptcy discharge may play other roles that improve social welfare. Among others, debt discharge may provide debtors with consumption insurance against adverse shocks. To address this issue, we ask whether bankrupt households consume more than what they would if they did not file for bankruptcy. In theory, the positive wealth shock induced by debt discharge suggests that bankrupt households would consume more upon filing for bankruptcy. On the other hand, the negative financial consequences of an effective tax on future earnings (under Chapter 13) seems to argue for the opposite conclusion. Moreover, the difficulty of gaining access to the credit market after filing for bankruptcy would lead households to cut their consumption, though it is not clear whether the cut would be greater than it would be if they had to repay their debts.

The PSID provides information on food consumption. We use the same methodology as in the benchmark (Section 3.3) to estimate the effect of filing for bankruptcy on food consumption. To do so, we replace log annual work hours with log inflation-adjusted food consumption. Data on food consumption are not available for 1988 and 1989. We also delete observations with zero food consumption. The final sample consists of 33, 438 observations on 5,748 households with 146 bankruptcy filings. We find that the bankrupt households consumed more than what they would have consumed if they had not filed for bankruptcy, but the estimated coefficient is statistically insignificant (table is not shown). Our consumption estimation, therefore, implies that there may be a role for bankruptcy provisions as a

\footnotetext{
${ }^{19}$ Using only years with wealth surveys (that is, 1984, 1989, and 1994) yields only fifty bankruptcy cases, which will significantly increase the imprecision of our estimation.
} 
social insurance program that helps households maintain certain desired consumption level when adverse shocks occur.

\section{Conclusions and Future Research}

The primary goal of the debt discharge in the U.S. personal bankruptcy law is to preserve human capital by maintaining incentives to work. In this paper, we provided the first quantitative analysis of the effect of filing for personal bankruptcy on the labor supply. In our empirical estimations, we control for both endogenous decision of bankruptcy filing and heterogeneity across households. We find that for households that filed for bankruptcy, neither the head of household alone nor the head and the wife jointly worked more hours than they would have worked if they had not filed for bankruptcy. To the contrary, all of the estimated effects of personal bankruptcy on the labor supply are negative, though not statistically significant at the usual confidence levels. Our findings, therefore, do not support the long-held belief in the "fresh start" effect of personal bankruptcy. Consequently, bankruptcy provisions for debt discharge cannot be justified on the ground of labor efficiency concerns.

Although bankruptcy discharge does not appear to achieve the desired effect on work incentives, our analysis does not rule out other roles of the bankruptcy provisions. For example, debt discharge can provide debtors with consumption insurance against adverse shocks. Using the PSID data on food consumption, we find that the bankrupt households indeed consumed more under personal bankruptcy than what they would have consumed if they had not filed for bankruptcy. The estimate, however, is not statistically significant.

For future research, one question of great policy importance is, how do the two bankruptcy chapters (i.e., Chapter 7 and Chapter 13) differ in their effects on the labor supply of bankrupt households? Because of the relatively small number of bankruptcy filings in the current PSID data, if we allow the labor supply to vary with different chapters, we would introduce large imprecisions in our estimations. We, therefore, shall revisit the question when additional data become available. We also left out other important and related issues. One such issue is the effect of bankruptcy provisions on small business formation. There are two interesting questions here. The first one is whether bankrupt entrepreneurs more likely start new business again after filing for personal bankruptcy than they would if they had to repay all their debts. This question is parallel to the labor supply issue studied in this paper. The second question is whether generous bankruptcy provisions encourage business

formation in general. We could not use the PSID data to answer the first question because only 17 entrepreneurs filed for bankruptcy in our sample. For the second question, while 
further studies are still needed, White (2001) does find that generous bankruptcy provisions encourage business formation. Elul and Gottardi (2003) also provide a theoretical analysis of business formation and personal bankruptcy. 


\section{References}

[1] Anonymous Author. 1755. Some Reflections on the Law of Bankruptcy Wrote at the Desire of a Friend, Shewing, That Such a Law Would Be Beneficial to the Publick, and Analogous to Reason and Our Holy Religion, and by Him Humbly Recommended to the Consideration of the Publick. New-Haven: Printed by James Parker. Rare Books, the Library of Congress.

[2] Athreya, K. 2002. Welfare Implications of the Bankruptcy Reform Act of 1999. Journal of Monetary Economics, 49(8), 1567-95.

[3] Buckley, F., and M.F. Brinig. 1998. The Bankruptcy Puzzle. Journal of Legal Studies, 27, 187-207.

[4] Chatterjee, S., D. Corbae, M. Nakajima, and J. Rios-Rull. 2001. A Quantitative Theory of Unsecured Consumer Credit with Risk of Default. Working Paper No. 02-6, Federal Reserve Bank of Philadelphia.

[5] Dawsey, A.E. and L.M. Ausubel. 2002. Informal Bankruptcy. Manuscript.

[6] Domowitz, I. and R. L. Sartain. 1999. Determinants of the Consumer Bankruptcy Decision. Journal of Finance, 54, 403-20.

[7] Elul, R. and N. Subramanian 2002. Forum-Shopping and Personal Bankruptcy. Journal of Financial Services Research, 21(3), 233-55.

[8] Elul, R. and P. Gottardi. 2003. Personal Bankruptcy and Incentives in a Dynamic Model of Entrepreneurship. Manuscript.

[9] Fay, S., E. Hurst, and M.J. White. 2002. The Household Bankruptcy Decision. American Economic Review, 92(3), 706-18.

[10] Gropp, R., J.K. Scholz, and M.J. White. 1997. Personal Bankruptcy and Credit Supply and Demand. Quarterly Journal of Economics, 112, 217-51.

[11] Gross, D.B., and N.S. Souleles. 2002. Explaining the Increase in Bankruptcy and Delinquency: Stigma versus Risk-Composition. Review Financial Studies, 15(1), 319-47.

[12] Hausman, J. A., J. Abrevaya, and F.M., Scott-Morton. 1998. Misclassification of the Dependent Variable in a Discrete-Response Setting. Journal of Econometrics, 87(2), $239-69$. 
[13] Heckman, J.J., R.J. Lalonde, and J.A. Smith. 1999. The Economics and Econometrics of Active Labor Market Programs. In the Handbook of Labor Economics, 3A, 1865-2097. Edited by Orley Ashenfelter and David Card.

[14] Hirsch, Adam J. 1994. Inheritance and Bankruptcy: The Meaning of the "Fresh Start." 45 Hastings Law Journal 175-248.

[15] Li, W., and D.G. Sarte. 2003. The Macroeconomics of U.S. Consumer Bankruptcy Filing: Chapter 7 or Chapter 13? Federal Reserve Bank of Philadelphia Working Paper 03-14.

[16] Lin, Emily Y. and Michelle J. White. Bankruptcy and the Market for Mortgage and Home Improvement Loans. Journal of Urban Economics, July 2001, v. 50, iss. 1, pp. $138-62$

[17] Livshits, I., J. MacGee, and M. Tertilt. 2001. Consumer Bankruptcy: A Fresh Start. Federal Reserve Bank of Minneapolis Working Paper 617.

[18] Jackson T.H. 1998. The Logic and Limits of Bankruptcy Law. BeardBooks, Washington, D.C.

[19] Jankowski D. 1999. National Mortgage Services Reference Directory. Perry Hall, Md. Vernon Enterprises.

[20] Jappelli, T., J. Pischke and N.S. Souleles. 1998. Testing for Liquidity Constraints in Euler Equations with Complementary Data Sources. Review of Economics and Statistics, 251-62.

[21] Keyles, S.A. 1995. Foreclosure Law and Related Remedies: A State-by-State Digest. Chicago, IL. Section of Real Property, Probate and Trust Law. American Bar Association.

[22] Krueger, A.B. and B.D. Meyer. 2002. Labor Supply Effects of Social Insurance. Handbook of Public Economics, 4, edited by Alan J. Auerbach and Martin Feldstein. Elsevier Science Pub. Co.

[23] Lin, E.Y. and M.J. White. 2001. Bankruptcy and the Market for Mortgage and Home Improvement Loans. Journal of Urban Economics, 50, 138-62.

[24] Mester, L. 2002. Is the Personal Bankruptcy System Bankrupt? Business Review, Federal Reserve Bank of Philadelphia, Quarter 1, 31-44. 
[25] Moffitt, R. 2002. Welfare Programs and Labor Supply. In Handbook of public economics, 4, edited by Alan J. Auerbach and Martin Feldstein. Elsevier Science Pub. Co.

[26] Musto, D.K. 2002. What Happens When Information Leaves a Market? Evidence from Post-bankruptcy Consumers. Journal of Business, forthcoming.

[27] Repetto, A. 1998. Personal Bankruptcies and Individual Wealth Accumulation. MIT. Ph.D. dissertation.

[28] Ruhm C. 1997. Is High School Employment Consumption or Investment? Journal of Labor Economics, 14(4), 735-76.

[29] Sullivan, T.A., E. Warren, and J.L. Westbrook. 1989. As We Forgive Our Debtors. New York: Oxford University Press.

[30] Sullivan, T.A., E. Warren, and J.L. Westbrook. 2000. The Fragile Middle Class. Yale University Press. New Haven and London.

[31] U.S. Supreme Court. 1934. Local Loan Co. V. Hunt, 292 U.S. 234.

[32] White M.J. 1998. Why Don’t More Households File for Bankruptcy? Journal of Law, Economics, and Organization, 14(2), 205-31.

[33] White M.J. 2001. Bankruptcy and Small Business. Regulation, 24(2), 18-20. 
Table 1: Homestead and nonhomestead exemptions by state, 1983 and 1992, in dollars

\begin{tabular}{lllll}
\hline \multirow{2}{*}{ State } & \multicolumn{3}{c}{1983} & \multicolumn{2}{c}{1992} \\
\cline { 2 - 5 } Alabama & Homestead & Nonhomestead & Homestead & Nonhomestead \\
Alaska & $5,000^{*}$ & $3,000^{*}$ & $5,000^{*}$ & $3,000^{*}$ \\
Arizona & $27,000^{*}$ & $1,500^{*}$ & 54,000 & $3,000^{*}$ \\
Arkansas & 50,000 & 7,600 & 100,000 & $1,650^{*}$ \\
California & No limit & 950 & No limit & $1,700^{*}$ \\
Colorado & 45,000 & 2,500 & 75,000 & 1,600 \\
Connecticut & 20,000 & 5,000 & $30,000^{*}$ & $1,000^{*}$ \\
D.C. & $7,500^{*}$ & $4,000^{*}$ & $7,500^{*}$ & $5,350^{*}$ \\
Delaware & $7,500^{*}$ & $4,000^{*}$ & $7,500^{*}$ & $5,350^{*}$ \\
Florida & 5,000 & 75 & 0 & $500^{*}$ \\
Georgia & No limit & $1,000^{*}$ & No limit & $1,000^{*}$ \\
Hawaii & 5,000 & 4,500 & $5,000^{*}$ & $1,500^{*}$ \\
Idaho & 20,000 & 1,000 & $20,000^{*}$ & $1,000^{*}$ \\
Illinois & $1,200^{*}$ & $4,000^{*}$ & $50,000^{*}$ & $1,500^{*}$ \\
Indiana & $7,500^{*}$ & $2,750^{*}$ & $7,500^{*}$ & $3,200^{*}$ \\
Iowa & 7,500 & 4,100 & $7,500^{*}$ & $4,100^{*}$ \\
Kansas & 500 & 4,000 & No limit & $5,100^{*}$ \\
Kentucky & No limit & 500 & No limit & $20,000^{*}$ \\
Louisiana & 5,000 & 6,000 & $5,000^{*}$ & $3,500^{*}$ \\
Maine & 15,000 & No limit & 15,000 & No limit \\
Maryland & $7,500^{*}$ & $2,300^{*}$ & $7,500^{*}$ & $6,100^{*}$ \\
Massachusetts & 2,500 & 3,500 & 0 & $5,500^{*}$ \\
Michigan & 60,000 & 3,500 & 100,000 & $1,675^{*}$ \\
Minnesota & $7,500^{*}$ & $4,000^{*}$ & $7,500^{*}$ & $5,350^{*}$ \\
Mississippi & No limit & 9,500 & No limit & $3,000^{*}$ \\
Missouri & 30,000 & 8,000 & $75,000^{*}$ & $10,000^{*}$ \\
Montana & 8,000 & 3,500 & 8,000 & $1,750^{*}$ \\
Nebraska & 40,000 & 200 & $40,000^{*}$ & 1,200 \\
Nevada & 6,500 & 5,500 & $10,000^{*}$ & $2,500^{*}$ \\
New Hampshire & 5,000 & 5,500 & $30,000^{*}$ & $6,200^{*}$ \\
\hline & & & $30000^{*}$ & $1,000^{*}$ \\
\hline
\end{tabular}




\begin{tabular}{lllll}
\hline \multicolumn{2}{l}{ continued from previous page } & \multicolumn{3}{c}{1992} \\
\cline { 2 - 5 } State & Homestead & Nonhomestead & Homestead & Nonhomestead \\
\hline New Jersey & $7,500^{*}$ & $4,000^{*}$ & $7,500^{*}$ & $5,350^{*}$ \\
New Mexico & $20,000^{*}$ & $6,500^{*}$ & $20,000^{*}$ & $4,500^{*}$ \\
New York & $10,000^{*}$ & $5,600^{*}$ & $10,000^{*}$ & $4,900^{*}$ \\
North Carolina & 7,500 & 8,500 & $10,000^{*}$ & $5,000^{*}$ \\
North Dakota & 80,000 & 10,000 & $80,000^{*}$ & $6,200^{*}$ \\
Ohio & $7,500^{*}$ & $4,000^{*}$ & $5,000^{*}$ & $1,800^{*}$ \\
Oklahoma & No limit & 5,000 & No limit & $3,000^{*}$ \\
Oregon & 15,000 & 2,650 & 15,000 & 8,700 \\
Pennsylvania & $7,500^{*}$ & $4,000^{*}$ & $7,500^{*}$ & $5,350^{*}$ \\
Rhode Island & $7,500^{*}$ & $4,000^{*}$ & $7,500^{*}$ & $5,350^{*}$ \\
South Carolina & 5,000 & 3,750 & $7,500^{*}$ & $5,350^{*}$ \\
South Dakota & No limit & 2,400 & No limit* & 4,000 \\
Tennessee & 5,000 & 4,750 & 5,000 & $4,000^{*}$ \\
Texas & No limit & 30,000 & No limit & $30,000^{*}$ \\
Utah & 8,000 & 3,000 & 8,000 & $1,500^{*}$ \\
Vermont & 30,000 & No limit & $30,000^{*}$ & $10,600^{*}$ \\
Virginia & $3,500^{*}$ & $5,000^{*}$ & $5,000^{*}$ & 2,000 \\
Washington & 30,000 & 6,750 & $30,000^{*}$ & $2,600^{*}$ \\
West Virginia & 5,000 & 1,000 & $7,500^{*}$ & $1,600^{*}$ \\
Wisconsin & 25,000 & 900 & 40,000 & $2,200^{*}$ \\
Wyoming & $10,000^{*}$ & $3,000^{*}$ & $10,000^{*}$ & $2,000^{*}$ \\
\hline
\end{tabular}

Notes: (a) The above values of exemption limits are for single filers. (b) * indicates that the exemption is doubled for married couples who file for bankruptcy together. (c) We use the federal exemption if the state permits filers to choose the federal exemption and the federal limit exceeds the state limit.

Source: Gropp, Schola and White (1997), and White (1998). 
Table 2: Homestead and non-homestead exemptions by state, 1993 - 1996, in dollars

\begin{tabular}{llll}
\hline Year & State & Homestead & Non-homestead \\
\hline \multirow{2}{*}{1993} & Connecticut & $75,000^{*}$ & unchanged \\
& New Mexico & $30,000^{*}$ & unchanged \\
& Minnesota & unchanged & $3,200^{*}$ \\
& Montana & unchanged & 2,250 \\
& Oregon & unchanged & 9,200 \\
1994 & D.C. & $15,000^{*}$ & $10,700^{*}$ \\
& Michigan & $15,000^{*}$ & $10,700^{*}$ \\
& New Jersey & $15,000^{*}$ & $10,700^{*}$ \\
& Pennsylvania & $15,000^{*}$ & $10,700^{*}$ \\
& South Carolina & $15,000^{*}$ & $10,700^{*}$ \\
1995 & Maine & $12,500^{*}$ & $2,900^{*}$ \\
& Vermont & $75,000^{*}$ & unchanged \\
1996 & Minnesota & 200,000 & unchanged \\
& California & unchanged & $2,500^{*}$ \\
\hline
\end{tabular}

Notes: (a) We only report states that have changed exemptions, either homestead or nonhomestead, between 1993 and 1996. (b) The above values of exemption limits are for single filers. (c) * indicates that the exemption is doubled for married couples who file for bankruptcy together. (d) We use the federal exemption if the state permits filers to choose the federal exemption and the federal limit exceeds the state limit.

Source: Lin and White (2001). 
Table 3: State garnishment laws

\begin{tabular}{|c|c|c|c|}
\hline State & Wage garnishment (\%) & State & Wage garnishment (\%) \\
\hline Alabama & FED & Montana & 10 \\
\hline Alaska & FED & Nebraska & 15 \\
\hline Arizona & FED & Nevada & FED \\
\hline Arkansas & FED & New Hampshire & 0 \\
\hline California & FED & New Jersey & 10 \\
\hline Colorado & FED & New Mexico & FED \\
\hline Connecticut & FED & New York & 10 \\
\hline D.C. & FED & North Carolina & 0 \\
\hline Delaware & 15 & North Dakota & FED \\
\hline Florida & FED & Ohio & FED \\
\hline Georgia & FED & Oklahoma & FED \\
\hline Hawaii & 19 & Oregon & FED \\
\hline Idaho & FED & Pennsylvania & 0 \\
\hline Illinois & 15 & Rhode Island & FED \\
\hline Indiana & FED & South Carolina & 0 \\
\hline Iowa & FED & South Dakota & 20 \\
\hline Kansas & FED & Tennessee & FED \\
\hline Kentucky & FED & Texas & 0 \\
\hline Louisiana & FED & Utah & FED \\
\hline Maine & FED & Vermont & 0 \\
\hline Maryland & FED & Virginia & FED \\
\hline Massachusetts & FED & Washington & FED \\
\hline Michigan & FED & West Virgina & 20 \\
\hline Minnesota & FED & Wisconsin & 20 \\
\hline Mississippi & FED & Wyoming & FED \\
\hline Missouri & FED & & \\
\hline
\end{tabular}

Notes: "FED" indicates that the federal maximum of $25 \%$ garnishment allowable binds. Source: Dawsey and Ausubel (2002). 
Table 4: Descriptive statistics of major variables, entire sample versus bankruptcy sample

\begin{tabular}{lllllll}
\hline & \multicolumn{3}{c}{ Entire sample } & \multicolumn{3}{c}{ Bankruptcy sample } \\
\cline { 2 - 7 } Variable & Mean & S.d. & Median & Mean & S.d. & Median \\
\hline Age & 39 & 10 & 37 & 35 & 9 & 34 \\
Head male* & 81 & 39 & & 73 & 45 & \\
Head white* $^{*}$ & 67 & 47 & & 62 & 49 & \\
Education ( $\geq$ high school)* $^{*}$ & 83 & 38 & & 83 & 38 & \\
Own house* & 63 & 48 & & 47 & 50 & \\
Own business* & 12 & 33 & & 8 & 27 & \\
Married* & 67 & 47 & & 59 & 49 & \\
Number of children & 1.1 & 1.1 & 1.0 & 1.4 & 1.2 & 1.0 \\
Experienced unemployment & 1.1 & 10 & & 3.3 & 18 & \\
$\quad$ in previous year* & & & & & & \\
Experienced bad health & 0.9 & 10 & & 1.4 & 12 & \\
$\quad$ in previous year* & & & & & & \\
Divorced in previous year* & 1.4 & 12 & & 4.2 & 20 & \\
Head's hours worked & 2142 & 665 & 2080 & 2122 & 607 & 2060 \\
Head's wage & 11.2 & 13.5 & 9.2 & 8.0 & 9.9 & 6.7 \\
Wife's age & 25 & 19 & 30 & 19 & 16 & 24 \\
Wife's education & 43 & 50 & & 36 & 48 & \\
$\quad(\geq$ high school)* & & & & & & \\
Wife's wage & 8.65 & 11.77 & 6.86 & 5.04 & 3.39 & 4.30 \\
Nonexempt assets $(\$)$ & 71529 & 397176 & 1181 & 7859 & 24053 & 0 \\
Unsecured debt $(\$)$ & 2905 & 16635 & 440 & 5087 & 9575 & 1730 \\
Family hours worked & 3037 & 1237 & 2934 & 2871 & 1199 & 2483 \\
Family income (\$) & 36000 & 34714 & 29748 & 23676 & 14777 & 21573 \\
\hline
\end{tabular}

Note: (a) The values of all financial variables are in real dollars, deflated by total CPI, 1982$84=100$. (b) S.d.: Standard deviation. (c) * indicates dummy variables. Means of dummy variables are expressed in percent, and their medians are not reported.

Source: The PSID, 1984-1996, total number of observations for the whole sample is 48, 834, the number of observations for the bankruptcy sample is 213 . 
Table 5: Probit estimation of determinants of bankruptcy filing

\begin{tabular}{llll}
\hline Variable & Coeff. & S.d. & Marginal effect \\
\hline Age of household head $^{2}$ & $4.67 \mathrm{e}-03$ & 0.02 & $1.44 \mathrm{e}-05$ \\
Age $^{2}$ & $-1.34 \mathrm{e}-04$ & $2.79 \mathrm{e}-04$ & $-3.90 \mathrm{e}-07$ \\
Education (high school or above) & 0.05 & 0.08 & $1.35 \mathrm{e}-04$ \\
Race (white $=1$ ) & 0.03 & 0.07 & $8.11 \mathrm{e}-05$ \\
Gender (male $=1)$ & -0.10 & 0.10 & $-3.27 \mathrm{e}-04$ \\
Marital status (married $=1)$ & $0.02^{*}$ & 0.10 & $5.56 \mathrm{e}-05$ \\
Number of children & $0.04^{* *}$ & 0.02 & $1.23 \mathrm{e}-04$ \\
Own home & -0.01 & 0.07 & $-2.31 \mathrm{e}-05$ \\
Self-employed & -0.10 & 0.11 & $-2.85 \mathrm{e}-04$ \\
Family income (previous year, $\$ 1,000 \mathrm{~s})$ & $-4.78 \mathrm{e}-03$ & $6.31 \mathrm{e}-03$ & $-1.07 \mathrm{e}-05$ \\
Family income squared & $-1.58 \mathrm{e}-05$ & $6.93 \mathrm{e}-05$ & $-5.33 \mathrm{e}-08$ \\
Head's wage (previous year) & $-0.02^{* *}$ & 0.01 & $-5.62 \mathrm{e}-05$ \\
Unsecured debt ( $\$ 1,000 s)$ & $0.05^{*}$ & $7.45 \mathrm{e}-03$ & $1.39 \mathrm{e}-04$ \\
Unsecured debt squared & $-6.29 \mathrm{e}-04^{*}$ & $1.72 \mathrm{e}-04$ & $-1.77 \mathrm{e}-06$ \\
Nonexempt asset (\$1,000s) & $-3.69 \mathrm{e}-03^{*}$ & $1.62 \mathrm{e}-04$ & $-1.03 \mathrm{e}-05$ \\
Nonexempt asset squared & $3.47 \mathrm{e}-07^{*}$ & $1.69 \mathrm{e}-07$ & $9.72 \mathrm{e}-10$ \\
Unsecured debt $*$ nonexempt assets & $-8.66 \mathrm{e}-07$ & $1.11 \mathrm{e}-04$ & $-6.18 \mathrm{e}-09$ \\
Divorced in previous year & $0.39^{* *}$ & 0.21 & $2.03 \mathrm{e}-03$ \\
Experienced unemployment in previous year & $0.31^{* *}$ & 0.17 & $6.76 \mathrm{e}-04$ \\
Experienced bad health in previous year & 0.17 & 0.22 & $6.56 \mathrm{e}-04$ \\
Maximum state wage garnishment rate $(\%)$ & 0.03 & 0.37 & $7.49 \mathrm{e}-05$ \\
Lagged state unemployed rate & 0.02 & 0.03 & $5.43 \mathrm{e}-05$ \\
Lagged state income growth rate & $1.66 \mathrm{e}-03$ & 0.02 & $4.28 \mathrm{e}-06$ \\
Lagged state bankruptcy filing rate & $0.66^{*}$ & 0.33 & $1.84 \mathrm{e}-03$ \\
\hline
\end{tabular}

Note: (a) The values of all financial variables are in real dollars, deflated by total CPI, 1982-84=100. (b) Coefficients on time and region dummies are not reported. (c) The marginal effects for discrete variables are for discrete change of their values from 0 to 1 . (d) Standard deviations (S.d.) are corrected for dependence across observations of the same household. (e) ${ }^{*}$ and ${ }^{* *}$ indicate statistically significant at the $95 \%$ and the $90 \%$ confidence levels, respectively. 
Table 6: The effects of bankruptcy filing on the labor supply of the head of household: Results using the Contemporaneous Selection Control approach

\begin{tabular}{lll}
\hline Variable & Coefficient & Standard error \\
\hline Age of household head $^{2}$ & $0.02^{*}$ & $4.89 \mathrm{e}-3$ \\
Age $^{2}$ & $-3.18 \mathrm{e}-04^{*}$ & $6.07 \mathrm{e}-05$ \\
Education (high school or above) & $0.08^{*}$ & 0.02 \\
Race (white $=1$ ) & $0.10^{*}$ & 0.01 \\
Gender (male = 1) & $0.14^{*}$ & 0.02 \\
Marital status (married =1) & $-1.06 \mathrm{e}-03$ & 0.02 \\
Number of children & $-6.86 \mathrm{e}-03$ & $5.29 \mathrm{e}-3$ \\
Own home & $0.05^{*}$ & 0.02 \\
Self-employed & $-0.10^{*}$ & 0.02 \\
Family income in previous year (\$1,000s) & $5.85 \mathrm{e}-03^{*}$ & $1.99 \mathrm{e}-03$ \\
Family income squared & $-1.11 \mathrm{e}-05$ & $1.41 \mathrm{e}-05$ \\
Wage rate in previous year & $-5.43 \mathrm{e}-03^{*}$ & $1.58 \mathrm{e}-03$ \\
Divorced in previous year & $7.37 \mathrm{e}-03$ & 0.05 \\
Experienced unemployment in previous year & $-1.29^{*}$ & 0.15 \\
Experienced bad health in previous year & $-0.94^{*}$ & 0.13 \\
Maximum state wage garnishment rate $(\%)$ & -0.07 & 0.06 \\
Lagged state unemployment rate & $-1.51 \mathrm{e}-02^{*}$ & $4.09 \mathrm{e}-03$ \\
Lagged state income growth & $-2.80 \mathrm{e}-03$ & $3.22 \mathrm{e}-03$ \\
Bankruptcy dummy (1 if bankrupted and 0 if not) & 0.57 & 0.39 \\
Inverse Mill's ratio for the repaid & 0.05 & 0.90 \\
Inverse Mill's ratio for the bankrupt & -0.16 & 0.14 \\
\hline Memo item: & & \\
Effect of bankruptcy filing & -0.01 & 2.45 \\
\hline
\end{tabular}

Notes: (a) The values of financial variables are in real dollars, deflated by total CPI, 1982$84=100$. (b) Coefficients on time and region dummies are not reported. (c) Standard errors are corrected for dependence across observations of the same household and are obtained through bootstrapping. (d) ${ }^{*}$ and ${ }^{* *}$ indicate statistically significant at the $95 \%$ and the $90 \%$ confidence levels, respectively. (e) The effect of bankruptcy filing is calculated for an average bankruptcy filer according to equation (15). 
Table 7: The effects of bankruptcy filing on the labor supply of the head of household: Results using the Instrumental Variable approach

\begin{tabular}{lll}
\hline Variable & Coefficient & Standard error \\
\hline Age of household head & $0.02^{*}$ & $4.44 \mathrm{e}-3$ \\
Age $^{2}$ & $-3.36 \mathrm{e}-04^{*}$ & $5.44 \mathrm{e}-05$ \\
Education (high school or above) & $0.09^{*}$ & 0.02 \\
Race (white $=1$ ) & $0.10^{*}$ & 0.01 \\
Gender (male =1) & $0.15^{*}$ & 0.02 \\
Marital status (married $=1)$ & $1.87 \mathrm{e}-02$ & 0.02 \\
Number of children & $-9.55 \mathrm{e}-03^{*}$ & $4.85 \mathrm{e}-3$ \\
Own home & $0.06^{*}$ & 0.01 \\
Self-employed & $-0.09^{*}$ & 0.02 \\
Family income in previous year (\$1, 000s) & $3.50 \mathrm{e}-03^{*}$ & $4.09 \mathrm{e}-04$ \\
Family income squared & $-3.38 \mathrm{e}-06^{*}$ & $7.16 \mathrm{e}-07$ \\
Wage rate in previous year & $-2.20 \mathrm{e}-03$ & $1.20 \mathrm{e}-03$ \\
Divorced in previous year & $1.77 \mathrm{e}-03$ & 0.04 \\
Experienced unemployment in previous year & $-1.30^{*}$ & 0.13 \\
Experienced bad health in previous year & $-0.94^{*}$ & 0.13 \\
Maximum state wage garnishment rate & -0.07 & 0.06 \\
Lagged state unemployment rate & $-1.61 \mathrm{e}-02^{*}$ & $3.95 \mathrm{e}-03$ \\
Lagged state income growth & $-2.81 \mathrm{e}-03$ & $3.29 \mathrm{e}-03$ \\
Probability of filing for bankruptcy & -0.17 & 1.42 \\
\hline
\end{tabular}

Notes: (a) The values of financial variables are in real dollars, deflated by total CPI, 1982$84=100$. (b) Coefficients on time and region dummies are not reported. (c) Standard errors are corrected for dependence across observations of the same household and are obtained through bootstrapping. (d) * and ${ }^{* *}$ indicate statistically significant at the $95 \%$ and the $90 \%$ confidence levels, respectively. 
Table 8: The effects of bankruptcy filing on the labor supply of the head and the wife of household: Results using the Contemporaneous Selection Control approach

\begin{tabular}{lll}
\hline Variable & Coefficient & Standard error \\
\hline Age of household head & $0.03^{*}$ & $4.69 \mathrm{e}-3$ \\
Age $^{2}$ & $-4.64 \mathrm{e}-04^{*}$ & $6.06 \mathrm{e}-05$ \\
Education (high school or above) & $0.06^{*}$ & 0.02 \\
Race (white = 1) & $0.05^{*}$ & 0.01 \\
Gender (male = 1) & $0.26^{*}$ & 0.02 \\
Marital status (married = 1) & $0.34^{*}$ & 0.04 \\
Number of children & $-0.04^{*}$ & $5.71 \mathrm{e}-3$ \\
Own home & $0.05^{*}$ & 0.01 \\
Self-employed & $-0.11^{*}$ & 0.03 \\
Family income in previous year (\$1000s) & $8.90 \mathrm{e}-03^{*}$ & $2.79 \mathrm{e}-03$ \\
Family income squared & $-1.94 \mathrm{e}-05$ & $1.96 \mathrm{e}-05$ \\
Wage rate in previous year (head) & $-0.01^{*}$ & $2.54 \mathrm{e}-03$ \\
Divorced in previous year & -0.03 & 0.05 \\
Experienced unemployment in previous year & $-1.08^{*}$ & 0.11 \\
Experienced bad health in previous year & $-0.73^{*}$ & 0.13 \\
Wife's age & $-1.12 \mathrm{e}-03$ & $1.09 \mathrm{e}-03$ \\
Wife's education (high school or above) & 0.02 & 0.02 \\
Wife's wage in previous year & $4.08 \mathrm{e}-03^{*}$ & $8.80 \mathrm{e}-04$ \\
Maximum state wage garnishment rate & $7.01 \mathrm{e}-03$ & 0.06 \\
Lagged state unemployment rate & $-1.72 \mathrm{e}-02^{*}$ & $4.27 \mathrm{e}-03$ \\
Lagged state income growth & $-3.16 \mathrm{e}-03$ & $2.95 \mathrm{e}-03$ \\
Bankruptcy dummy (1 if bankrupt and 0 if not) & -0.08 & 0.35 \\
Inverse Mill's ratio for the repaid & 0.17 & 1.06 \\
Inverse Mill's ratio for the bankrupt & 0.07 & 0.12 \\
\hline Memo item: & -0.36 & 2.86 \\
Effect of bankruptcy filing & & \\
\hline
\end{tabular}

Notes: (a) The values of financial variables are in real dollars, deflated by total CPI, 1982$84=100$. (b) Coefficients on time and region dummies are not reported. (c) Standard errors are corrected for dependence across observations of the same household and are obtained through bootstrapping. (d) ${ }^{*}$ indicates statistically significant at the $95 \%$ confidence level. (e) The effect of bankruptcy filing is calculated for an average bankruptcy filer according to equation (15). 